\title{
The Effect of Religiousity in Choice of Saving in Sharia Banks Using Multinominal Logistic Approach
}

\author{
Aglis Andhita Hatmawan \\ Faculty of Economics and Business Universitas PGRI Madiun \\ namaku.aglis@gmail.com
}

\begin{abstract}
The aim of the research is to analyze the effect of religiosity on the choice of saving in Sharia banking in Madiun. This type of research is explanatory research using survey research design. The subjects of this study were Sharia and conventional banking customers in Madiun. The samples used in this study were 685 samples using purposive sampling technique. The analysis technique used in this study is multinominal logit. The results of this study indicated that religiosity affects the probability of the customer's choice to save in Sharia banking is lower than saving together in a sharia and conventional bank and only saving in conventional bank. This shows that religiosity influences the probalility of saving only in Sharia banking dominated by emotional religious ideological mindset rather than economic rational mindset of customer.
\end{abstract}

Keywords: Religiosity, Sharia Banks.

\section{Introduction}

As the largest Muslim population country in the world, Indonesia has great potential to become the center of the development of the Sharia finance industry. However, the growth of Sharia finance has not been able to keep up with conventional financial growth. This can be seen from the market share of Sharia finance as a whole is still below 5\%. It means there is still a low level of Muslim community that uses Sharia banking services in Indonesia generally. This research attempts to answer this phenomenon.

Savings have an important role both micro and macro. In the macro, the tube is one of the sources of investment to increase the economic growth of the country [1]. While microsavings has an important role for someone in order to maintain the level of consumption in the future [2]. In facts, many different views about the factors that determine a person to save and choose where he will save. According to [3] these view differences are caused by the lack of an appropriate model to explain and describe precisely the observed community or individual saving behavior.

Based on existing theories, there is a major mainstream in studying the behavior of saving, namely the classical belief and the Keynesian belief. Both believe in the influence of interest rates. According to Keynes, the influence of the interest rate on savings is very complex and many possibilities will occur [4]. Based on the research conducted [5] states that there are two important decision factors in one's saving behavior, the first is how much income is used for consumption and the second is how much income he sets aside to save. Some 
researches conducted by [6], [7], [8] and [9] state that the influence of self-control influences a person to save.

One's self-control is certainly influenced by one of them is religiosity [10] this also applies to one's saving behavior when he will decide where he will save and how much he saves. Religiosity is the main factor of a person's saving behavior, this is supported by research conducted by [11], [12], [13],[14] which state that religiosity is the main motivation of someone bumping behavior. On the other hand, religiosity is not a major factor in saving this in accordance with research conducted by (Erol, et all, 1990), [16], [17], [18], [19],[20].

\section{Literature Review}

\subsection{Consumer Choice Theory}

The important decision that everyone faces is how much income will be used for current consumption and how much income will be used for future consumption purposes. Another decision is how and how much money will be saved because it depends on the prevailing interest rates [21]. Consumer choice theory can be used to analyze how people make decisions about their income to save or spend on consumption in the present. Also how the amount of money deposited depends on interest rates or not.

In general, everyone's saving behavior is determined by two important decision factors. First refers to some of the real income received will be used for consumption purposes. Second refers to how much real income money is received will be set aside for savings. Long before [22] described consumption / savings planning can be simplified into two periods, namely present and future. On the other hand, for consumption decisions everyone will maximize utility throughout the life period. But in maximizing the utility of each person is very limited the ability of the budget owned. Thus, actually everyone faces a trade off. Rational choice theory [23] states that social behavior (including economic behavior) is influenced by four factors. One of them is wert rational. This theory illustrates that human rational behavior cannot be separated from the belief in certain absolute values, such as religious values (religiosity), ethics and aesthetics or other values believed.

\subsection{Religiocity}

Economic behavior is largely determined by the level of one's faith or society. This behavior then forms the tendency of consumption and production behavior in the market. This perspective also influences saving behavior [12] Religion is a system that has been institutionalized in every society and is fundamentally a binding norm in everyday life. Religious teachings that have been understood can motivate the lives of individuals in interacting with God and fellow humans, even with the environment.

Religiosity is manifested in various aspects of human life. Religious activity does not occur only when someone performs ritual behavior (worship of maghdah) only. But it is appreciated into social life (worship of ghairu maghdah), including banking practices as part of economic muamalah.

[24] analyzes religiosity into five dimensions, namely ideological/ belief dimensions, ritualistic/ practical, experiential/ experience, intellectual / knowledge, and consequences:

First, the idiological dimension/ belief is concerned with how much a person believes in the truth of his religious teachings, especially towards fundamental or dogmatic teachings. In Islam, the contents of the dimension of belief are related to beliefs about the existence of God, Angels, Apostles / Prophets, the book of God, heaven, hell, qodho and qodar [25].

Second, the ritualistic/ practical dimension relates to how much a person obeys in doing ritual activities as ordered or encouraged by the religion he adheres to. In Islam, the contents 
of the ritualistic / practical dimension include activities such as performing prayers, fasting, hajj (if capable), reading the Qur'an, climbing prayers, etc. [25].

Third, experiential dimensions regarding how a person feels and experiences unreligious feelings and experiences. In Islam, the content of the experiential dimension includes feeling close to God, being loved by God, prayers are often granted, a feeling of peace and happiness in obeying God [25], and being saved from disaster, receiving income that was not thought of before, such as grants, gifts and inheritance.

Fourth, the intellectual / knowledge dimension is related to how much a person has knowledge and understanding of his religious teachings, especially regarding the basic teachings as contained in his holy book.

In Islam, the content of the intellectual/ knowledge dimension includes knowledge of the contents of the Quran, the points of teachings that must be believed and implemented, Sharia law [25], and understanding of Sharia economic/ Sharia banking scientific principles.

Fifth, the dimension of practice/ consequence relates to how much a person behaves in a manner motivated by his religious teachings. The behavior in question is worldly behavior, namely how individuals relate to their world. In Islam, the contents of the dimensions of practice/ consequences include helping behavior, giving charity, upholding truth and justice, being honest, keeping the mandate, protecting the environment, not stealing, not gambling, not deceiving, struggling for the success of life according to Islam [25], adhere to and implement Sharia norms in culture, society, politics, and economics (business/ banking transactions) nonusury thus, religiosity can be described as a form of consistency between belief in religion as a cognitive element, feeling of religion as an affective element and religious behavior as a psychomotor element [26]. Religiosity is a complex integration between religious knowledge, feelings and religious actions in a person in all aspects of life.

\section{Method}

This type of research is explanatory research using survey research design and uses a quantitative approach to the choice of saving in Sharia banking. The subjects in this study were Sharia banking customers in Madiun. Methods in collecting data using a questionnaire that lists questions that are filled in by respondents who meet the criteria to be sampled.

The population in this study were customers of Sharia banking and conventional banks in Madiun, the sample used in this study was 685 samples with purposive sampling technique. With a number of consideration criteria, namely customers who have savings accounts, have carried out transactions in banks, have had a savings account for 1 year, at the time of opening a customer account open an account voluntarily not because someone else opened it.

\section{Result}

Respondents in this study were conventional and sharia bank customers in Madiun. The distribution of respondents is shown in Table 1.

The majority of respondents who save in Sharia banks and conventional banks are aged over 40 years. [27], that at the age of over 31 years, customers think the future for their children, so they will save more to prepare for education fees as early as possible. By sex $56 \%$ of women and $44 \%$ of men. This shows that the majority of respondents the most are women. [28] states that most customers are dominated by women. This condition is caused because women in Indonesia tend to be holders of family financial control and more time to transact with banks than men. Whereas based on the work, the majority of the respondent's work is private employees, namely $56 \%$, civil servants as much as $25 \%$, employers as much as $16 \%$ and students as much as 6\%. Based on Khoiron's statement (2010) that employment affects 
income, it can be assumed that customer income can affect customer relationships with banks. At the education level banking customers in Madiun are undergraduate. Logically, the higher the level of one's education, the higher the quality of one's thinking, which is the tendency to always act with the consideration of rationality arguments [7].

Table 1. Respondents Profile

\begin{tabular}{|c|c|c|c|c|c|c|}
\hline \multirow[b]{2}{*}{ Profile } & \multirow[b]{2}{*}{ Descriptions } & \multicolumn{3}{|c|}{ Total of Respondents } & \multirow[b]{2}{*}{ Total } & \multirow[b]{2}{*}{ Percentage } \\
\hline & & Conv & $\begin{array}{c}\text { Sharia \& } \\
\text { Conv }\end{array}$ & Sharia & & \\
\hline \multirow[t]{5}{*}{ Age } & $20-24$ & 11 & 9 & 7 & 27 & $4 \%$ \\
\hline & $25-29$ & 36 & 29 & 23 & 88 & $13 \%$ \\
\hline & $30-34$ & 56 & 45 & 36 & 137 & $20 \%$ \\
\hline & $35-39$ & 56 & 45 & 36 & 137 & $20 \%$ \\
\hline & $>40$ & 121 & 97 & 78 & 296 & $43 \%$ \\
\hline \multirow[t]{2}{*}{ Gender } & Male & 123 & 99 & 78 & 300 & $44 \%$ \\
\hline & Female & 157 & 126 & 102 & 385 & $56 \%$ \\
\hline \multirow[t]{4}{*}{ Job } & Students & 17 & 13 & 12 & 42 & $6 \%$ \\
\hline & Private & 149 & 120 & 94 & 363 & $56 \%$ \\
\hline & Entrepreneurs & 44 & 36 & 29 & 109 & $16 \%$ \\
\hline & Civil Servants & 70 & 56 & 45 & 171 & $25 \%$ \\
\hline \multirow[t]{4}{*}{$\begin{array}{l}\text { Level of } \\
\text { Education }\end{array}$} & $\begin{array}{l}\text { Undergraduat } \\
\mathrm{e}\end{array}$ & 25 & 31 & 40 & 96 & $14 \%$ \\
\hline & Diploma & 49 & 44 & 38 & 131 & $19 \%$ \\
\hline & Bachelor & 120 & 97 & 94 & 311 & $45 \%$ \\
\hline & Post Graduate & 86 & 53 & 8 & 147 & $21 \%$ \\
\hline
\end{tabular}

The Multinomial Logit Model is useful for modeling customer savings behavior decisions in Madiun. In this case, the dependent variable is the customer decisions to save in Madiun. Decisions are classified into three, namely (1) saving only in Sharia banks; (2) saving in Sharia banks and conventional banks; and (3) only saving in conventional banks. Religiosity variable, being an independent variable that influences customers to save in Sharia banks in Madiun.

Logistic regression results require an evaluation to find out how well the logistic regression results are. Logistical regression evaluation results include:

a) Size of logistic regression Goodness of fit is called Pseudo R2, which is indicated by Negelkerke R2 value of 0.848 . This value means that the Religiosity variable is able to explain the customer's choice of saving by $84 \%$, while the remaining $16 \%$ is explained by other variables outside the research model;

b) Uji (b) Overall Model Fit test by inserting independent variables into the results model is better than the model that only includes intercepts -2 log likelihood with interception 1481.752, whereas by entering an independent variable, $2 \log$ likelihood fell to 531,803 or there was a decrease in Chi-square by 949,949 and was significant at $p=0.00$. In short, the model with independent variables provides better accuracy for predicting the choice of customers to save in Sharia banks Madiun.

c) Significance Test 
The significance test of independent variables can be done in two ways, namely the Likelihood Ratio Test and the Wald Test.

1. Likelihood ratio test

Variables contributes to the model with significance $\mathrm{P}<0.05)$. It can be concluded that, the variables of religiosity affect the choice of customers to save in Sharia banks in Madiun.

2. Wald Test.

As for the government apparatus, the telephone is used by the village officials, district and sub-district officials in coordinating their daily work affairs such as meeting preparation and others. Work affairs for the village community, a telephone is used as a communication tool in finding job and employment affairs. For family members who work in big cities such as in Jakarta, or abroad such as in Saudi Arabia, Malaysia, Hong Kong, they can deliver messages and receive messages from their employers when they are home.

Table 2. Likelihood Ratio Tests

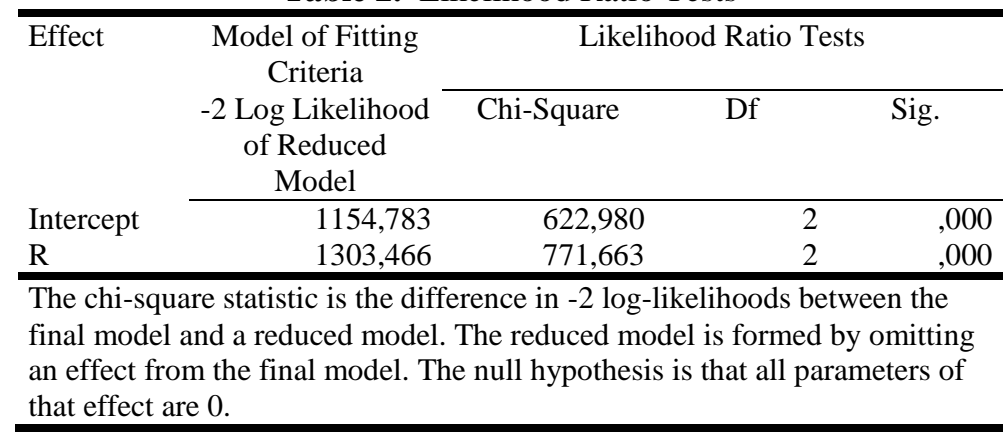

Table 3. Wald Tests

\begin{tabular}{|c|c|c|c|c|c|c|c|c|c|}
\hline \multicolumn{2}{|c|}{ Saving Behaviour ${ }^{\mathrm{a}}$} & \multirow[t]{3}{*}{$\mathrm{B}$} & \multirow[t]{3}{*}{ Std. Error } & \multirow[t]{3}{*}{ Wald } & \multirow[t]{3}{*}{ Df } & \multirow[t]{3}{*}{ Sig. } & \multirow{3}{*}{$\begin{array}{l}\text { Exp( } \\
\text { B) }\end{array}$} & \multicolumn{2}{|c|}{$\begin{array}{c}\text { 95\% Confidence } \\
\text { Interval for } \operatorname{Exp}(B)\end{array}$} \\
\hline & & & & & & & & Lower & Upper Bound \\
\hline & & & & & & & & Bound & \\
\hline & Intercept & 28,585 & 2,263 & 159,598 & 1 &, 000 & & & \\
\hline \multirow[t]{2}{*}{1,00} & $\mathrm{R}$ &,- 336 &, 176 & 130,553 & 1 &, 000 & ,699 & ,343 &, 574 \\
\hline & Intercept & 14,282 & 1,365 & 109,416 & 1 &, 000 & & & \\
\hline 2,00 & $\mathrm{R}$ &,- 289 &, 152 & 94,451 & 1 &, 000 & ,495 & ,458 & ,828 \\
\hline
\end{tabular}

a. The reference category is: 3,00 .

The results of the hypothesis testing show that the level of religiosity of customers who save only in Sharia banks has a positive and significant influence on attitudes towards the intention to save in Sharia banking. From the analysis of Glock and Stark's theory of religiosity, this empirical phenomenon can be understood both in ideological/ belief aspects, 
rituals, intellectual/ religious knowledge, and experience, as well as in the aspects of consequences/ application.

The results of this analysis reinforce the findings. In general, the level of religiosity of Muslim customers who save only in Sharia banks is very good (very high). This condition shows that the contribution of religiosity to saving behavior in Sharia banks is quite convincing.

The study of [29] in Pakistan shows that the strong Sharia vision (religiosity) of customers encouraging business transactions only through Sharia banking is a significant factor. The strength of Sharia vision (religiosity) simultaneously encourages public perception, that the interest rate on savings is not a problem for customers who only save in Sharia banks. They prefer a legitimate or permissible investment return on religion, not a matter of how high and low this return is when compared to the interest rate or inflation of conventional banks. Muslim societies that save in conventional banks are due to a lack of knowledge that Islam prohibits the payment and receipt of interest.

The effect of religiosity on saving behavior in Sharia banks as reflected in this study proves the existence of an ideological-emotional mindset is more dominant than an economical rational mindset in customers who only have savings in Sharia banks. This type of customer group, as concluded does not think the high and low profitability of the savings return received.

The influence of religiosity that strengthens attitudes on the intention to save in Sharia banks as reflected in this research proves the existence of ideological-emotional mindset is more dominant than the rational mindset of customers who only have savings in Sharia banks. This type of customer group, as concluded by [12] and [27] does not think the high and low profitability of the savings return received. This group thinks like the conclusions of [17] study in Kuwait, Saudi Arabia and Egypt which shows that most Muslims in the dual banking system choose banks for religious reasons. Moreover, Sharia banks-according to customers are no different from conventional banks in staff returns and competencies and service speed.

According to [12], the economic behavior of Muslim customers who do not have an account in conventional banking is largely determined by the level of ideology/ belief. This behavior then forms a tendency for consumption and production behavior in the market. This perspective also influences saving attitudes and behavior. When trust exists at a fairly good level, the economic motives (consuming/ saving or producing) will be dominated by mashlahah motives (public interest), needs and obligations. This character is called as a devout Muslim. When measures of economic behavior are seen in terms of banking utilization, according to [12] this group can be classified as Muslims who truly avoid interest-based conventional banks.

The results of previous studies which concluded that religiosity is not a major and insignificant factor in the choice of savings customers in Sharia banks found the background of profitability, pricing, demographic preferences, and alternative financial institutions as important and main factors. Profitability preferences related to the view of profit sharing from Sharia bank savings is greater than the interest income from conventional bank savings. Pricing is related to the view of the costs of savings administration not being applied or lower than in conventional banks. Even in certain Sharia banks nullify administrative costs to customers

Demographics relate to the view of the closeness of the bank office, the quality of service (fast, efficient, and friendly). The consideration of religion is not at all an election consideration for Sharia banks. Utilization of Sharia banks is used as an alternative to conventional banks due to profitability, pricing and demographic factors. 
When linked to this research model, the majority of upper middle income customers will choose to save in conventional banks or have accounts in conventional and Sharia banks can be explained that the rational mindset (due to economic profitability) of customers. Economic background becomes dominant for customers choosing Sharia or conventional banks because of profitability, pricing, and demographic excellence. [16], and [30], Both studies concluded that the motivation of customers to choose/ take advantage of Sharia banking seems to be dominated by factors of profitability, pricing, and quality of services provided by Sharia banks. Therefore, the relationship between non-Muslim customers and Sharia banks is built on the commitment of transactive rationality.

Customers who choose to only save in conventional banks or save in Sharia and conventional banks, which are the findings of this study, reflect a rational mindset (due to economic profitability) of customers. Economic background becomes dominant for customers choosing Sharia banks because of profitability, pricing, and demographic excellence. This empirical fact led to the conclusion, that groups of customers who save in Sharia banks and conventional banks or only save in conventional banks are economically rational customers (the behavior of establishing a relationship with a bank because of merely encouraging consideration of economic utility).

\section{5 . Conclusion}

A person's religiosity affects someone choosing to save. In terms of the analysis of Glock and Stark's theory of religiosity, this empirical phenomenon is understood as good in ideological/ belief aspects, rituals, intellectual/ religious knowledge, and experience, as well as in the aspects of consequences / application. The results of this analysis reinforce the findings, that in general the level of religiosity of Muslim customers who save only in Sharia banks is very good (very high). This condition shows that the contribution of religiosity to saving behavior in Sharia banks is quite convincing.

Doubts about the position of interest are in the category of usury and therefore illicit law encourages these customers to continue to have relations with conventional banking. This customer group considers the actual profit sharing equal to interest, Sharia banking operations are the same as conventional banking. Understanding like this actually does not stand alone. This group of customers lives in a patinialistic socio-religious structure.

The structure of socio-religious life of the East Javanese community, especially in Madiun, which is more patriarchal, makes this group more confident with its role model social organization. Although the MUI has issued a fatwa on the law of bank interest, it is haram, but it does not seem to provide a widespread and massive influence.

\section{References}

[1] Todaro, Pembangunan Ekonomi di Dunia Ketiga. Jakarta: Erlangga.

[2] Dynan, "Do the rich save more?," J. Polit. Econ., pp. 397-444.

[3] P. Fisher, "Saving Behavior of U.S. Households: A Propect Theory Approach," Ohio State University, 2006.

[4] Mikell, "The Nature of Saving Function In Developing Countries: A Survey of The Theoretical and Emperical Literature," J. Econ. Lit. XI.

[5] Mukhlis, Perilaku Menabung Di Perbankan Syariah Jawa Tengah. Universitas Diponegoro.

[6] S. Lim, "The analysis of psychological factors affecting savers in Malaysia," Middle East. Financ. Econ., vol. 12, pp. 77-85, 2011.

[7] M. Thung, "Determinants of saving behaviour among the university students in 
Malaysia," Univ. Tunku Abdul Rahman, p. 109, 2012.

[8] A. Wahana, "Analisis faktor-faktor yang mempengaruhi perilaku mahasiswa dalam menabung (studi kasus mahasiswa strata satu fakultas ekonomika dan bisnis universitas diponegoro. Program Sarjana Fakultas Ekonomika Dan Bisnis Universitas Diponegoro.”

[9] H. Sirine, Faktor - faktor Yang Mempengaruhi Perilaku Menabung di Kalangan Mahasiswa. Jurnal Ekonomi Dan Bisnis.

[10] A. Bergin, "Religiousness \&Mental Health Reconsidered," J. Counscling Psychol., pp. 197-204, 1987.

[11] H. Okumus, "Interest-Free Banking in Turkey: A Study of Customer Satisfactin and Bank Selection Criteria," J. Econ. Coop., pp. 51-86.

[12] M. al Hassan, "People's Perceptions towards the Islamic Banking: A Fieldwork Study on Bank Account Holders' Behaviour in Pakistan," Sch. Econ., pp. 467-850, 2007.

[13] Abdelghani, "Malaysian consumers' preferences for Islamic banking attributes," Int. J. Soc. Econ., vol. 39, pp. 859-874.

[14] H. Sayani, "Determinants of bank selection in the United Arab Emirates," Int. J. Bank Mark., pp. 206-228.

[15] C. Erol, E. Kaynak, E1-Bdour, and R., "Conventional and Islamic Bank: Patronage Behaviour of Jordanian Customers,” Ional J. Bank Mark., vol. 8, pp. 25-35.

[16] A. N. and P. S. Haron, S, "Bank Patronage Factors of Muslim and Non-Muslim Customers," Int. J. Bank Mark., vol. 12, no. 1, pp. 32-40, 1994.

[17] Metwally, "The Impact of Demographic Factors on Consumers' Selection of a Particular Bank within a Dual Banking System: A Case Study,” Res. J. Int. Mark. Mark., pp. 3544.

[18] M. A. Nizar, Analisis Perilaku Menabung Masyarakat Dalam Deposito Pada Bank Syari'ah Paska Fatwa Mui Tentang Keharaman Bunga. Jurnal Keuangan Dan Moneter.

[19] Adawiyah, Pertimbangan, Pengetahuan, Dan Sikap Konsumen Individu Terhadap Bank Syariah. Jurnal Ekonomi Pembangunan.

[20] J. K. Bley, "Conventional versus Islamic finance: student knowledge and perception in the United Arab Emirates," Int. J. Islam. Financ. Serv., pp. 17-30.

[21] G. N. Mankiw, Principles of Economics. Singapore: Cengage Learning Asia Pte Ltd.

[22] R. Crouch, Mcroeconomics. USA: Harcourt Brace Jovanovich, Inc.

[23] M. Weber, The Protestant Ethics and The Spirit of Capitalism. New York: Charles Scribner's Sons.

[24] C. Y. and R. S. Glock, American Piety: The Nature of Religious Commitment. USA: University of Chicago Press, 1968.

[25] S. Ancok, Psikologi Islami. Yogyakarta: Pustaka Pelajar, 2002.

[26] J. Rakhmat, Psikologi Agama. Jakarta: PT. Raja Grafindo Persada.

[27] K. S. E. Alzafiri, "Cost of Capital of Islamic Banking Institutions: an Empirical Study of a Special case," Int. J. Islam. Middle East. Financ. Manag., vol. 1.

[28] N. Hidayati, "Beban Ganda Perempuan Bekerja (antara Domestik dan Publik)," Dalam J. Muwazah, vol. 7.

[29] M. Hasan and E. Harris, Entrepreneurship and innovation in e-commerce. The University of New South Wales. International OCSCO World Press.

[30] I. Hegazy, "An Empirical Comparative Study between Islamic and Commercial Banks' Selection Criteria in Egypt," Int. J. Commer. Manag. 